\title{
Sultan Aqung

\section{The Existence of A Single Submission Online Institution in Land Technical Considerations}

\author{
Susi Andriyani ${ }^{*}$ and Ira Alia Maerani**) \\ *) Faculty of Law, Universitas Islam Sultan Agung (UNISSULA) Semarang, E-mail: \\ susiandriyani1969@gmail.com \\ ${ }^{* *}$ Faculty of Law, Universitas Islam Sultan Agung (UNISSULA) Semarang
}

\begin{abstract}
The enactment of Government Regulation Number 24 of 2018 which introduced the Online Single Submission (OSS) institution brought many changes in various fields, one of which was in the field of land services. This study analyzes the implementation of land technical considerations through the OSS institution and the obstacles in the implementation of land technical considerations through the OSS institution. The research method used is normative legal research with a statutory approach and a conceptual approach. The results of the study indicate that the Implementation of Land Technical Considerations through the OSS institution is intended to provide convenience in obtaining permits in order to improve the investment climate in Indonesia.
\end{abstract}

Keywords: Licensing; Land Technical Considerations; OSS.

\section{Introduction}

Improving investment licensing in Indonesia is a homework that never seems to be done properly. Business licensing bureaucracies often even incur high costs in the business world, because of the unofficial fees involved in managing these business licenses. This certainly greatly affects the investment climate in Indonesia. ${ }^{1}$

In recent years, the flow of world globalization has become increasingly rapid. This makes the investment climate even better. The ease of doing business in a country will make investors come and invest their capital. One of the indicators to assess Indonesia's competitiveness is the ease of investment. An important step that needs to be taken for ease of doing business is to reform regulations related to investment or business in Indonesia. Regulatory reform is one of the important agendas that Indonesia needs to do, to improve the quality of regulations. ${ }^{2}$

One of the strategies that the government has taken to support the ease of doing business in Indonesia is the issuance of Government Regulation Number 24 of 2018 concerning Electronically Integrated Business License Services (PP No. 24 of 2018).

\footnotetext{
${ }^{1}$ Sentosa Sembiring, 2018, Hukum Investasi, Nuansa Aulia, Bandung, p. 106

${ }^{2}$ Ima Mayasari, "Evaluasi Kebijakan Izin Lokasi dan Pertimbangan Teknis Pertanahan Pasca Penerapan Online Single Submission", Jurnal Rechtsvinding, Vol. 8 No. 3, December 2019, p. 404
} 
Article 1 number 5 PP No. 24 Th. 2018 states that Electronically Integrated Business Licensing or Online Single Submission (OSS) is a Business Licensing issued by the OSS Institution for and on behalf of the minister, agency head, governor, or regent/mayor to Business Actor through an integrated electronic system. While what is meant by the OSS Institution is stated in Article 1 number 11 PP No. 24 Th. 2018 as follows:

The transformation of technological progress has made Indonesia enter the disruption era, where innovation is very important. The development of this technology also affects the laws and regulations governing business licensing in Indonesia. ${ }^{3}$ The implementation of the OSS system is intended to catch up with Indonesia in facilitating licensing services from neighboring countries such as Vietnam, Malaysia and Singapore. With the promulgation of PP No. 24 Th. 2018 certainly fundamentally changed the permit issuance system in Indonesia. OSS is intended to make it easier for business actors to obtain legality. Trimming the old procedure where at first the permit applicant met the requirements before obtaining a business license, now through OSS, business actors are given ease of information and clarity of procedures at various stages. ${ }^{4}$

The enactment of PP No. 24 Th. 2018 which introduced the OSS institution brought many changes in various fields, one of which was in the field of land services. The Minister of Agrarian and Spatial Planning/Head of the National Land Agency responded to the application of the Online Single Submission (OSS) by issuing a Regulation of the Minister of Agrarian and Spatial Planning/Head of the National Land Agency Number 15 of 2018 concerning Land Technical Considerations (Permen ATR/Ka.BPN No. 15 Th. 2018) as well as updating the regulation on location permits through the Regulation of the Minister of Agrarian Affairs and Spatial Planning/Head of the National Land Agency Number 17 of 2019 concerning Location Permits (Pemen ATR/Ka.BPN No. 17 of 2019).

Based on the things above, this research focuses on the existence of an online single submission institution in land technical considerations with the formulation of the problems in the research, namely: how to implement land technical considerations through the OSS institution and the obstacles in implementing land technical considerations through the OSS institution.

\section{Research Methods}

This research is a normative legal research (doctrinal legal research). As is the type of normative research, the approach method used in this research is the statute approach and the conceptual approach. ${ }^{5}$ Research sources can be divided into primary,

\footnotetext{
${ }^{3}$ Hatta Isnaini Wahyu Utomo, "Tantangan Pelaksanaan Jabatan Notaris Di Era Revolusi Industri 4.0", Paper, presented in the Public Lecture of Masters of Notary Public Lecture Narotama University Surabaya, September 2019, p. 2

${ }^{4}$ Desi Arianing Arrum, "Kepastian Hukum Dalam Perizinan Berusaha Terintegrasi Secara Elektronik (Online Single Submission) di Indonesia", Jurnal Juris-Diction, Vol. 2 No. 5, September 2019, p. 1635

5I Made Pasek Diantha, 2017, Metodologi Penelitian Hukum Normatif, Prenada Media Group, Jakarta, p. 156
} 
secondary, and tertiary legal sources. The collection of legal materials is done by means of library research. ${ }^{6}$ The results of the analysis of legal materials will be interpreted using systematic and grammatical interpretation methods. ${ }^{7}$

\section{Result and Discussion}

One of the Nawa Cita agenda mandates that Indonesia can become an economically independent and competitive nation. Improving economic competitiveness through a conducive investment climate is one of Indonesia's national priorities as stated in the 2015-2019 National Medium-Term Development Plan (RPJMN 2015-2019). ${ }^{8}$ The emphasis on increasing economic competitiveness needs to be directed where one of them is improving the investment climate and business climate, and to achieve this agenda, the government has made various efforts, one of which is issuing various economic deregulation packages to increase competitiveness and economic growth. Apart from enforcing and guaranteeing legal certainty, the target of deregulation is the simplification of bureaucratic processes that can have a positive impact on competitiveness, ease of doing business, and economic growth.

The ease of doing business ranking, published by the World Bank, in the Doing Business Measuring Business Regulations, Ranking and Score of the Ease of Doing Business (Ease of Doing Business) in 2019, Indonesia is ranked 73rd (seventy three) in the Ease of Doing Business Rank. While ranking in Starting a Business, Indonesia is ranked 134th (one hundred and thirty-four). ${ }^{9}$ In the investment sector, each sector has arrangements for licensing mechanisms in the investment sector to be opened in Indonesia. Business licenses issued by ministries or agencies and local governments to start, implement and develop business activities, face problems related to their implementation. Restructuring regulations that support the acceleration of implementation is important to reduce obstacles to the development of business activities.

In general, it can be said that the quantity or number of laws and regulations in the business sector is disproportionate, and even tends to be over-regulated. Almost every agency whose duties and functions are related to the sector tries to form regulations and in the formation of these regulations do not coordinate with each other and instead prioritize their respective sectors. In addition, the legislators cannot/want to realize that the formation of legislation is actually a process of unifying or harmonizing

\footnotetext{
${ }^{6}$ Soerjono Soekanto and Sri Mamudji, 2005, Penelitian Hukum Normatif, Rajagrafindo Persada, Jakarta, 1985, p. 41

${ }^{7}$ Sudikno Mertokusumo, 1987, Penelitian Hukum, Liberty, Yogyakarta, p. 47

${ }^{8}$ BAPPENAS, 2014, Rencana Pembangunan Jangka Menengah Nasional 2015-2019, Book I, Agenda Pembangunan Nasional, Jakarta, p. 44

9 The World Bank, "Doing Business Measuring Business Regulations", https://www.doingbusiness.org/, accessed 17 August 2019
} 
various interests. Based on the above conditions, it can be said that the laws and regulations in the business sector cannot function optimally. ${ }^{10}$

Ida Bagus Rahmadi Supancana stated that there are 3 functions of regulation, namely: a) As a means of order or behavioral guidelines, ie regulation becomes a guideline for the implementation of social dynamics, in this case both for formal and informal activities; b) As a development instrument, ie regulation mobilizes resources to achieve a predetermined goal; and c) As an integration factor, ie regulation integrates areas and policies in the context of state administration and development into a National Regulatory System which is an aggregation of all existing regulations. ${ }^{11}$

In a modern legal state, the duties and authorities of the government are not only to maintain order and security (rust en orde), but also to seek public welfare (bestuurszorg). In order to realize the duties and authorities of the government, the law gives the government authority in the field of regulation. Based on this regulatory function, juridical instruments emerge in the context of dealing with individual and concrete events, namely in the form of provisions. One form of this provision is a permit. $^{12}$

Permit (vergunning) based on the concept in Act No. 30 of 2014 concerning Government Administration (Law No. 30 of 2014) is a decision by an authorized government official as a form of approval of the request of citizens in accordance with the provisions of the legislation. Permission is meant by the desire of the legislator to achieve a certain order or to prevent bad conditions. The aim is to regulate actions that are not entirely deemed reprehensible by legislators, but wish to be able to carry out minimal supervision. In a narrow sense, the concept of licensing is that actions are prohibited, unless they are permitted with the aim that in the provisions involved with approval certain limits can be given for each case. ${ }^{13}$

The OSS system came into effect on 9 July 2018 and was inaugurated by Coordinating Minister for Economic Affairs. The Electronically Integrated Business Licensing Service (PBTSE), which is more easily referred to by the generic name OSS, is present in the context of business licensing services that apply to all Ministries, Institutions, and Local Governments throughout Indonesia, which so far have been carried out through One Stop Licensing (One Stop Integrated Licensing). PTSP). Apart from PTSP, the public can access the OSS System online anywhere and anytime. OSS is the government's effort to simplify business licensing and create an integrated licensing service model that is fast and inexpensive, and provides certainty.

\footnotetext{
${ }^{10}$ Wicipto Setiadi, "Simplifikasi Peraturan Perundang-Undangan Dalam Rangka Mendukung Kemudahan Berusaha", Jurnal Rechstvinding, Vol. 7 No. 3, December 2018, p. 324

${ }^{11}$ Ida Bagus Rahmadi Supancana, "Better Regulations Tools in Policy Formulation", Paper, submitted in collaboration between the Center for Regulatory Studies (Center For Regulatory Research), The World Bank, Swiss Confederation, Kingdom of the Netherlands, dan Kementerian Perekonomian, Bandung, 2526 September 2017, p. 3

${ }^{12}$ Desi Arianing Arrum, Op. Cit., p. 1645

${ }^{13}$ Philipus M. Hadjon. ed, 1993, Pengantar Hukum Perizinan, Yuridika, Surabaya, p. 3
} 
The implementation of the OSS system provides various benefits, including: a) mfacilitate the management of various business licenses, both prerequisites for doing business (permits related to location, environment, and buildings), business permits, and operational permits for business operations at the central or regional level with a mechanism for fulfilling the permit requirements commitments; b) mfacilitate business actors to connect with all stakeholders and obtain permits safely, quickly and in real time; c) mfacilitating business actors in reporting and solving licensing problems in one place; and d) mfacilitating business actors to store licensing data in one business identity (NIB).

The authority to issue business permits is regulated in Article 18 PP No. 24 Th. 2018 which states that business permits are issued by the minister, head of institution, governor, or regent/mayor according to their authority. Furthermore, in Article 19 PP No. 24 Th. 2018 stated that the implementation of the authority to issue business licenses as referred to in Article 18 including the issuance of other documents related to business licensing must be carried out through the OSS Institution. (Article 19 PP No. 24 Year 2018). This means that the OSS Institution issues business permits for and on behalf of the minister, head of the institution, governor, or regent/mayor. ${ }^{14}$

The arrangement is in accordance with the principle of legality which states that the government's authority comes from laws and regulations. The principle of legality is the basis for the legitimacy of government actions and guarantees for the protection of people's rights. In other words, every state and government administration must have the principle of legitimacy. The application of the principle of legality will support the enforcement of legal certainty and equal treatment. Without the basic authority granted by an applicable statutory regulation, then all kinds of government officials will not have the authority to influence or change the state or legal position of their citizens. ${ }^{15}$

In land services, technical considerations for land are also carried out through the OSS institution in line with the enactment of the Minister of ATR/Ka.BPN No. 15 Th. 2018. As for the legislative ratio, the issuance of Permen ATR/Ka.BPN No. 15 Th. 2018 is to support the implementation of the provisions of PP No. 24 Th. 2018 so that the Land Technical Consideration service was adjusted. In Article 1 number 1 Permen ATR/Ka.BPN No. 15 Th. 2018 it is stated that Land Technical Considerations are considerations that contain provisions and conditions for the control, ownership, use and utilization of land by taking into account the suitability of spatial planning.

The objectives of the adjustment of the Land Technical Consideration service are, among others, to: a) accelerate and improve the quality of investment and business

\footnotetext{
${ }^{14}$ Monika Suhayati, "Permasalahan Perizinan Berusaha Terintegrasi Secara Elektronik (Online Submission System)", Jurnal Info Singkat, Research Center of the Indonesian House of Representatives Expertise Board, Vol. X No. 23, December 2018, p. 3

${ }^{15} J u n i a r s o ~ R i d w a n$ and Achmad Sodik Sudrajat, 2012, Hukum Administrasi Negara dan Kebijakan Pelayanan Publik, Nuansa, Bandung, p. 133-137
} 
services; b) realizing the efficient, effective and sustainable use and utilization of land; c) realizing a balance between land capability, land use and utilization and the environment; d) realizing equitable land tenure and ownership; e) realizing the designation, use and utilization of land in accordance with the Spatial Plan; and f) realizing control, ownership, use and utilization of land based on sustainable, optimal, harmonious and balanced principles in rural areas as well as safe, orderly, smooth and healthy in urban areas based on Spatial Planning.

In Article 4 of Permen ATR/Ka.BPN No. 15 Th. 2018 it was determined that Land Technical Considerations were given in the context of: a) approval/rejection of Location Permits; b) granting/extension or renewal of land rights; c) confirmation of status and recommendations for land tenure arise; or d) changes in land use and utilization. From the four criteria above, until now the Technical Considerations of Land through the OSS institution are still limited to approval/rejection of Location Permits only.

The subject of Land Technical Considerations in the context of approval or rejection of location permits is given to individual or non-individual Business Actors. Individual business actors are individuals who are Indonesian residents who are capable of acting and carrying out legal actions. Meanwhile, non-individual business actors consist of: a) limited liability companies; b) public company; c) regional public companies; d) other legal entities owned by the state; e) public service bodies; f) broadcasting institutions; g) a business entity established by a foundation; and h) cooperatives.

For a location permit application, the applicant must also attach the following requirements: a) Business Identification Number; b) Decision on the Granting of Location Permit and its Attachments; c) Statement of Fulfillment of Commitment or No Commitment; d) Map containing the coordinates of the location boundary polygons; e) Business activity plan or land use and utilization plan; and f) A statement regarding the location and area of land that has been controlled by business actors and other business actors who are part of the same group.

The land technical consideration process is carried out by going through the process of submitting an application file at the service counter/OSS, then the Land Technical Consideration Team carries out a site review, data processing and analysis, discussion meetings, compilation of minutes and maps, and determination, for then the Head of the Land Office provides technical considerations which is then submitted to the Regent/Mayor/Ka. PTSP to obtain a location permit approval/rejection decision.

OSS brings a breakthrough in automatic approval that uniforms requirements and there is no need for a document review process as long as it meets the administrative requirements in the portal, it will immediately get a business license. The basic difference between OSS and the previous licensing system is that initially in the licensing system, the permit applicant meets the requirements first, then gets a 
business license. Now through OSS, the permit applicant first gets a business license and then completes the requirements.

Changes that occur related to the implementation of technical considerations on land through OSS can be seen from the aspect of its position. Previously in the Regulation of the Head of the National Land Agency Number 2 of 2011 (Perkaban No. 2 of 2011), technical considerations on land were issued before the location permit was issued by the PTSP/Regent/Mayor, and became a consideration in the issuance of the location permit. ${ }^{16}$ Meanwhile, in Permen ATR/Ka.BPN No. 15 Th. 2018, given after the location permit is issued by the OSS Institution and as a basis for consideration the location permit is effective. Then in the issuance procedure, location permits are issued through OSS for Business Actors. The implementation period is also shorter from 14 (fourteen) days to 10 (ten) days. Furthermore, it is related to authority without being carried out in stages, meaning that currently it is only processed through the Regency/City Land Office.

The use of the OSS system in Land Technical Considerations is carried out by taking into account the Computerization of Land Activities (KPP). It is stated in Article 1 number 10 of Permen ATR/Ka.BPN No. 15 Th. 2018 that the KKP is the main application in supporting the implementation of the authority, duties and functions of the Ministry of Agrarian Affairs and Spatial Planning/National Land Agency based on information and communication technology that is built and developed referring to the flow, requirements, time, cost, and authority in accordance with the provisions of laws and regulations. invitation.

Problems that occur related to the use of the OSS system in Land Technical Considerations are related to not all Land Offices in Indonesia using this application. There are still certain areas that are far from big cities and do not have a quality internet connection that have not used the KPP application. For the occurrence of this condition in Article 18 of the Ministerial Regulation of ATR/Ka.BPN No. 15 Th. 2018 has regulated that if the Land Office has not used the KKP, notification of the completeness of the required documents and/or receipt of the application can be done directly without going through the OSS system.

\section{Closing}

\subsection{Conclusion}

The implementation of Land Technical Considerations is carried out through the OSS institution to provide convenience in obtaining permits in order to improve the investment climate. Land Technical Considerations implemented through the OSS system since the enactment of the Ministerial Regulation ATR/Ka. BPN No. 15 Th. 2018, but for now it is only limited to the application for a location permit which can be done through the OSS institution. The obstacle that exists in the use of the OSS

\footnotetext{
${ }^{16}$ Ima Mayasari, Op.Cit., p. 407
} 
system in Land Technical Considerations at this time is that not all Land Offices in Indonesia have used this application. There are still certain areas that are far from big cities and do not have a quality internet connection that have not used the KPP application. For the occurrence of these conditions, the application for a location permit can be carried out manually by directly coming to the local Land Office.

\subsection{Suggestion}

In the future, regarding the granting/extension or renewal of land rights, confirmation of status and recommendations for land tenure arising as well as changes in land use and utilization also need to be carried out through the OSS system. In addition, it is also necessary to do equality in the integration of the OSS system with KPP at Land Offices throughout Indonesia so that in the future there is no need for manual applications. This also aims to avoid extortion that can hinder investment in Indonesia.

\section{References}

Journals:

[1] Desi Arianing Arrum, "Kepastian Hukum Dalam Perizinan Berusaha Terintegrasi Secara Elektronik (Online Single Submission) di Indonesia", Jurnal Juris-Diction, Vol. 2 No. 5, September 2019, p. 1635

[2] Ima Mayasari, "Evaluasi Kebijakan Izin Lokasi dan Pertimbangan Teknis Pertanahan Pasca Penerapan Online Single Submission", Jurnal Rechtsvinding, Vol. 8 No. 3, December 2019, p. 404

[3] Monika Suhayati, "Permasalahan Perizinan Berusaha Terintegrasi Secara Elektronik (Online Submission System)", Jurnal Info Singkat, Research Center of the Indonesian House of Representatives Expertise Board, Vol. X No. 23, December 2018, p. 3

[4] Wicipto Setiadi, "Simplifikasi Peraturan Perundang-Undangan Dalam Rangka Mendukung Kemudahan Berusaha", Jurnal Rechstvinding, Vol. 7 No. 3, December 2018, p. 324

Books:

[1] BAPPENAS, 2014, Rencana Pembangunan Jangka Menengah Nasional 20152019, Book I, Agenda Pembangunan Nasional, Jakarta

[2] I Made Pasek Diantha, 2017, Metodologi Penelitian Hukum Normatif, Prenada Media Group, Jakarta

[3] Juniarso Ridwan and Achmad Sodik Sudrajat, 2012, Hukum Administrasi Negara dan Kebijakan Pelayanan Publik, Nuansa, Bandung

[4] Philipus M. Hadjon. ed, 1993, Pengantar Hukum Perizinan, Yuridika, Surabaya

[5] Sentosa Sembiring, 2018, Hukum Investasi, Nuansa Aulia, Bandung

[6] Soerjono Soekanto and Sri Mamudji, 2005, Penelitian Hukum Normatif, Rajagrafindo Persada, Jakarta

[7] Sudikno Mertokusumo, 1987, Penelitian Hukum, Liberty, Yogyakarta 
Regulations:

[1] Act No. 30 of 2014 concerning Government Administration

[2] Government Regulation Number 24 of 2018 concerning Electronically Integrated Business License Services

[3] Ministerial regulation Agrarian and Spatial Planning / Head of the National Land Agency Number 15 of 2018 concerning Land Technical Considerations

[4] Ministerial regulation Agrarian and Spatial Planning / Head of the National Land Agency Number 17 of 2019 concerning Location Permits

Others:

[1] Ida Bagus Rahmadi Supancana, "Better Regulations Tools in Policy Formulation", Paper, submitted in collaboration between the Center for Regulatory Studies (Center For Regulatory Research), The World Bank, Swiss Confederation, Kingdom of the Netherlands, dan Kementerian Perekonomian, Bandung, 25-26 September 2017

[2] Hatta Isnaini Wahyu Utomo, "Tantangan Pelaksanaan Jabatan Notaris Di Era Revolusi Industri 4.0", Paper, presented in the Public Lecture of Masters of Notary Public Lecture Narotama University Surabaya, September 2019

[3] The World Bank, "Doing Business Measuring Business Regulations", https://www.doingbusiness.org/, accessed 17 August 2019 